Rafael Bravo

University of Zaragoza (Spain)

Jesús Cambra

University Pablo de Olavide (Spain)

Edgar Centeno

AGADE, ITESM Monterrey (Mexico)

Iguácel Melero

University of Zaragoza (Spain)

\title{
The Importance of Brand Values in Family Business
}

\begin{abstract}
Only a small body of literature exists on linking key marketing concepts in family business contexts and those studies that do exist show a significant bias towards brand management. Both the relevance of the subject and the lack of research assuming this challenge to date justify the interest and timeliness of this literature review.

Based on this interest - and the existing research opportunities - this article presents the concept of brand, together with a framework for its analysis in family business contexts. The paper summarizes the six main lines of research proposed, three from the perspective of identity management, and three from the perspective of stakeholders. The last section presents a series of interesting aspects for carrying out future research.
\end{abstract}

Keywords: Marketing; Brand; Family Business

\section{Introduction}

Brand management is a fundamental issue in the field of marketing. It is, in fact, a concept of reference for several leading research institutions, including the American Marketing Association

Corresponding author: e-mail: rbravo@ unizar.es

Received 05 May 2017 - Accepted 17 May 2017

This is an Open Access article distributed under the terms of the Creative Commons Attribution-Non-Commercial-No Derivatives License (http://creativecommons.org/licenses/by-nc-nd/4.0/), which permits non-comercial re-use and distribution, provided the original work is properly cited, and is not altered or transformed in any way. 
or the European Marketing Academy. In the foremost marketing journals-e.g., Journal of Marketing, Marketing Science, Journal of Marketing Research, Journal of the Academy of Marketing Science, International Journal of Research in Marketing-articles on brand management appear on a regular basis. In addition, relevant specialized journals exist, such as Journal of Product and Brand Management or Journal of Brand Management.

As for the specific case of marketing literature in family business contexts, brand management seems to be the subject which, to date, has aroused the greatest interest. A preliminary search in the leading international marketing journals of reference, cited above (Family Business Review, Journal of Family Management) and in the most relevant SME journals (Journal of Small Business Management, International Small Business Journal)—using keywords like "marketing" and "family firms"_-resulted in 15 articles, of which almost half (seven) presented brand management as the central theme.

The above ideas suggest that, while the study of specific aspects of marketing in family business contexts has, thus far, sparked little interest, brand management—often understood as an extension of family image and identity — has indeed been more prominent. Reuber and Fischer (2011), published in Family Business Review suggest that (i) there may be more differences than similarities between family firms (size, experience, management style, resources); hence, the fact that more research opportunities arise when comparing family firms than when comparing family and non-family firms; and that, (ii) for many family businesses, it is important to know how they are perceived by the different stakeholders - what their image and reputation are and how these constructs evolve over time.

For all of these reasons, it seems fitting to contextualize the study of brand management in the context of family business. Both the relevance of the subject and the lack of research assuming 
this challenge to date justify the interest and timeliness of this literature review. Specifically, this article has three main objectives:

(i) To identify the most important studies on the concept of brand

(ii) To present a set of key considerations when adapting global concepts to the specific context of family firms

(iii) To put forward a series of interesting proposals for future research.

To this end, the following section presents the concept of brand and its evolution in scholarly research. In Section 3, the authors discuss brand management from the point of view of the company. Section 4 presents current brand-related issues and transitions into an introduction to specific aspects of brand in family business contexts. Finally, a series of options for future action are proposed.

\section{The concept of brand: evolution in scholarly Research}

Spanish Trademark Law 17/2001 (Ley de marcas 17/2001), currently in effect in Spain, defines brand as any symbol susceptible to graphic representation that may serve to distinguish the products or services of one company from those of others in the market. The raison d'être of brands, then, is to make it possible to distinguish between different products and services. This fundamental function can be considered to have existed since the Middle Ages, when merchants made first use of brands to help consumers distinguish between the products of different producers and guilds.

However, the scope the brand concept — and above all, brand management - have undergone notable changes since then. At present, brand not only applies to products and services but to establishments, people, places, organizations and ideas (American Marketing Association 2017) as well. This shift is reflected by the advent of brand-derived concepts such as personal 
branding, place branding and corporate branding. Moreover, brands have gone from targeting consumers, exclusively, to focusing on all stakeholders; and brand management has evolved from being primarily product-focused to an experience in which all contact points should be aligned. This evolution parallels developments in the area of marketing and is the result of changes in the environment. Hence, interest in concepts such as brand loyalty, for instance, derives from a paradigm shift in the company-consumer relationship (Fournier 1998); and the importance of current concepts such as brand communities, brand commitment and eWOM has its origin in the evolution of ICT and their increasing impact on the business of organizations (Pansari and Kumar 2016).

Among the most notable changes in the study of brands is the 1950's interest in the emotional component of brands - leading to changes in the way both the brand concept and the advertising of the time are understood. Years later, this emotional component would lead to the emergence of other concepts such as brand personality (Aaker 1997) and brand love (Batra, Ahuvia, and Bagozzi 2012). Today, new technologies and the spread of social networks continue to drive the evolution of brand communication. Companies have gone from mass to personalized communication (one-to-many, one-to-one), while consumers have gone from small to potentially large-scale communication (one-to-one, one-to-many) (Hewett et al. 2016). New technologies have also meant changes in the type of information available and, especially, in the ability to analyze huge amounts of data resulting from the connectivity of the brand with the stakeholders. Brand managers must know how to manage the single-channel nature of these stakeholders, in general, and consumers, in particular, if they are to direct appropriate actions towards each customer — and, above all, provide a consistent experience at each of the contact points (Velotsou and Guzman 2017). 
Interest in brand management in practice has been paralleled by scholarly development. Numerous papers have appeared on the subject in general marketing journals. Likewise, both national and international conferences have emerged, including the Global Branding Conference and the International Conference on Research on National Brand and Private Label Marketing (NB\&PL) — along with journals focused on brand management such as the Journal of Product and Brand Management, or the Journal of Brand Management.

In scholarly terms, a range of theories have been applied to the study of brand. Due to their transversal nature, these theories have sprung not only from marketing spheres but from fields such as business organization, psychology, sociology and even design. Among the most cited are associative network theory and signaling theory (Keller 1993; Aaker 1996; Stach 2015). In associative network theory, brand information is stored in the consumer's mind through a hierarchical network system. According to this theory-in synthesis-the mind of the individual is composed of nodes or concepts, connected to associations or information related to these nodes. In the specific case of brand, we could consider the brand as a node in the mind of the consumer; and as consumers come into contact with the brand, they will acquire information that they will link to that node. The more relevant the information be to the consumer or the more closely related it be to the brand, the stronger the connection between the node and that association. Based on this theory, Keller (1993) proposes to link the brand to positive, strong, unique associations. These associations are not necessarily related to the product but to other aspects such as the sales personnel places where the brand has been sold, or a particular occasion on which the consumer has used the brand (Keller 2003). The set of associations will comprise the meaning that the brand has for each consumer and serve as the basis for brand image. 
Signaling Theory refers to the information that companies provide through signals such as price, points of sale, communication, etc., as perceived by consumers (Rao et al. 1999; Pappu and Quester 2016). In the case of a brand that the consumer is not very familiar with, a high price can signal a quality product, for instance. Likewise, if the brand is sold in luxury establishments or if the firm carries out a careful communication campaign in which the quality of the product is emphasized, the consumer may perceive the product as being prestigious. In this sense, the brand would act as a plus sign, adding information and confidence to the purchase. Consumers will attribute a series of characteristics to the product or service, merely due to the brand. There are, in any case, numerous other theories on which research has been based, including the theory of accessibility and diagnosis, information integration theory and social identity theory (Ahluwalia and Gürhan-Canli 2000; Bhattacharya et al. 2003; Czellar 2003; Vernuccio et al. 2015).

\section{Brand identity management}

In addition to the consumer analysis perspective, a good deal of brand research has been devoted to the development process within the company. It is crucial to determine, here, the way in which brand identity is developed and the elements that compose it.

One salient literature review revealed that brand-building models may be categorised in two orientations: outside-in or inside-out, depending on the order in which brand owners wish to focus on growth. In general terms, Kapferer (2004) argues that there is no one best orientation. Other authors, however, suggest that firm size must be considered when selecting a brandbuilding orientation. Yet other authors suggest that perhaps it is essential to evaluate the potential for finding the perfect balance between both orientations (Ind and Bjerke 2007). No matter which orientation is used, it is important to clearly establish a roadmap and to be 
consistent during the brand-building period. Both brand orientations lead to the development of a specific set of brand elements first, followed by the others: inside-out brand building focuses on brand identity first, then brand image. Conversely, the outside-in orientation starts by analysing brand image first, then focusing on brand identity.

Inside-out brand building may be more suitable to family businesses. First, because specific variables beyond the firm's control—coupled with difficulties inherent to today's business environment-have arisen; as a result, family businesses may need to consider further. Technological advances, for instance, have made some branded products more vulnerable to copying. Hence, the surge in me-too products (de Chernatony and McDonald 2003; Kapferer 2004; King 1991) in terms of product attributes, as they are easily copied. In many cases, this situation has led to a lack of clear differentiation. There is some indication then, that brand differentiation may be found, not in terms of product attributes, but in brand equity including organizational values (Melewar and Saunders 1998). Secondly, media vehicle saturation has made it more difficult for brands to stand out among the communication clutter (Joachimsthaler and Aaker 1999). Hence, brands need to have a clear brand identity before going through the complex brand communication process. Third, when family firms lack sufficient financial, human, time or expertise resources to develop an effective brand image, brand identity becomes a key element to focus on first; in other words, if family businesses begin by developing the right brand identity — by clearly establishing what they want out of the brand — then brand image will be the second element to focus on.

There are numerous ways to define brand identity. Most authors, however, will agree that there is a common set of key characteristics: first, that the main purpose of brand identity is to convey the aim, competitive advantage, target brand associations and timeless essence of the brand; in 
short, what the firm aims to create and develop (Aaker and Joachimsthaler 2000; de Chernatony 2006; Ghodeswar 2008; Nandan 2005). More importantly, brand identity defines the values the firm strives to represent and support. Brand equity-more specifically termed customer-based brand equity $(C B B E)$ - is defined as those advantages which customers obtain in the long-term. Second, that brand identity represents, essentially, the brand's individuality or uniqueness (de Chernatony 2006; Ghodeswar 2008); what makes the brand relevant to consumers. This individuality, some authors suggest, is rooted in a unique set of characteristics which support a sustainable competitive advantage (Ghodeswar 2008). Yet other authors put forward that brand identity is the first block in brand-building (Aaker 1996; Keller 1993). According to Keller's Brand Equity Model $(2003,76)$, the first question customers ask about a brand is regarding its identity. Consumers ask "Who are you?" before moving on to the other questions on the Customer Based Brand Equity (CBBE) Pyramid.

As a building block, brand identity precedes other brand components such as brand image and brand positioning. For authors such as Kapferer (2004, 97), for instance, identity precedes image. This means that - before communicating the brand - firms must first develop a brand identity statement: "What makes our brand different?". Brand identity calls for determining which consumer needs will be satisfied prior to making decisions regarding which consumer needs will be communicated. Brand identity looks at what the market need is that the brand will strive to fill (Yakimova and Beverland 2005). Once this has been determined, the brand may move on to communicating its identity.

Confusion may arise between brand identity and brand image as these two concepts are sometimes used interchangeably (Ind 1990). This can be avoided by clearly defining these 
concepts with more precision (Christensen and Askegaard 2001). Table 1 shows the specific differences between brand identity and brand image.

As seen in Table1, while brand identity is developed by the firm, brand image is the outcome of consumer perceptions; hence, brand image must be preceded by brand identity.

Table 1. Characteristics of Brand Identity and Brand Image

\begin{tabular}{|l|l|}
\hline \multicolumn{1}{|c|}{ Brand Identity } & \multicolumn{1}{c|}{ Brand Image } \\
\hline $\begin{array}{l}\text { What the organisation aspires the brand to } \\
\text { become }\end{array}$ & $\begin{array}{l}\text { What customers and other stakeholders } \\
\text { perceive about the brand }\end{array}$ \\
\hline Should be active, future-oriented & Usually passive, past-oriented \\
\hline $\begin{array}{l}\text { Strategic, reflecting a business strategy that } \\
\text { will lead to sustainable advantage }\end{array}$ & Tactical \\
\hline Should include brand's enduring qualities & May include transitory characteristics \\
\hline $\begin{array}{l}\text { Company viewed as source of } \\
\text { communication }\end{array}$ & $\begin{array}{l}\text { Target audience viewed as receiver of } \\
\text { communication }\end{array}$ \\
\hline Created by brand management & Created by consumer perceptions \\
\hline Encoded & Decoded \\
\hline Identity is communicated & Image is received/perceived \\
\hline
\end{tabular}

Some authors argue that brand identity is more than a set of symbols. Aaker (1996), for instance, suggests that brand identity is composed of four dimensions brand as a product, brand as an organization, brand as a symbol and brand as a person. These dimensions affirm that brand identity is not made up of symbols alone; other elements are just as important for brand identity delivery. Other authors argue that brand identity may also include other brand components, such as brand positioning, brand vision, brand culture and the relationships forged among staff, staff and customers, and staff and other stakeholders (de Chernatony 2006). Moreover, Kapferer (2004) suggests that customer reflection and customer self-image components may also be included. 
For the purpose of this study, brand identity has been defined using Aaker's definition, as the unique set of target characteristics — including family values — created and developed by the family brand owner(s) based on the four brand image dimensions: brand as a product, brand as an organization, brand as a symbol and brand as a person. Since the product is the heart of the brand, one of the key decisions family brand owners must make is how to configure brand as a product. This dimension is where customers establish a relationship and connection with the brand.

It may be relevant, at this point, to define the product concept. A product is anything made available in the marketplace for purchase or consumption. Hence, products may be physical items, but may also be a service, a person, place or idea (Kotler et al. 2002). We use this broad definition for the purposes of this study.

Products, it is important to point out, are made up of different elements. Kotler (1991), for instance, proposes five levels to a product: the core benefit or equity, the generic product, the expected product, the augmented product and the potential product. Benefit/equity is the level from which all others are derived. Other authors argue that "a brand is therefore a product, but one that adds other dimensions that differentiate it in some way from other products designed to satisfy the same need" (Keller 2003, 57). In other words, products aid in establishing brand differentiation. Still other authors suggest that a branded product may be composed of attributes, benefits and values (Aaker 1996; Keller 2003).

Brand attributes are physical characteristics which may describe the product (Keller 2003). They include purely tangible traits making up the core product (de Chernatony and McDonald 2003). Some authors have suggested several classifications, as a means to better understand these traits. Attributes may be product-related and non-product related (Keller 2003) — for 
instance - intrinsic and extrinsic, with intrinsic attributes being perceptible or imperceptible (Riezebos 2003). Attributes fall into five categories: 1) primary ingredients and supplementary features, 2) product reliability, durability, and serviceability, 3) service effectiveness, efficiency and empathy, 4) style and design, and 5) price (Kotler 1991; Levitt 1980). It has also been established that consumers do not perceive all attributes as having the same level of importance. A hierarchy of attributes has been proposed - the most important being those that consumers use to decide which products to purchase (Riezebos 2003). That said, there is evidence that some irrelevant attributes may also have a positive impact on consumer perceptions regarding brand (Griffin and Hauser 1993).

Brand benefits have been defined as short-term advantages offered to consumers (Aaker 1996; Arnold 1992; Keller 2000; Keller 1993). Benefits can be functional or emotional. Keller (1993) and Aaker (1996) propose three categories: (i) functional benefits - benefits related to the product, (ii) experiential benefits - benefits which trigger a feeling linked to using a product, and (iii) symbolic benefits - benefits which garner social approval or enhance personal expression. The key difference between these benefits is that emotional benefits are not affected by changes in product attributes and may develop a different relationship with consumers (Aaker and Joachimsthaler 2000; Ghodeswar 2008). Important to note too is the fact that benefits should also be consistent to one another (Arnold 1992).

The definition of customer-based brand equity $(\mathrm{CBBE})$ has been discussed extensively. One definition is long-term stable advantages sought by consumers (Aaker 1996). When the concept is easily understood and valued by customers, CBBE has also been defined as the essence of the brand, (Arnold 1992). From the perspective of the consumer, equity exists when a brand costs less than competing brands with similar benefits (de Chernatony and McDonald 2003; 
Porter 1980). Consumers may also seek added-value in a brand seen as offering unique benefits worth paying a premium price for (de Chernatony and McDonald 2003). It has also been suggested that brand equity is a complex variable with different meanings and dimensions where emotional value may play an important role in defining added-value (de Chernatony et al. 2000). In terms of categories, Sheth et al. (1991) suggest five brand equity types: (i) functional value - the utility of a brand in relation to the functionality of its product, (ii) social value - the utility of a brand associated to a particular social group, (iii) emotional value - the utility of a brand associated with a particular feeling, (iv) epistemic value - the utility of a brand to arouse curiosity and (v) conditional value - the utility of a brand in a given situation. Additionally, Keller (2003) suggests that core brand equity helps positioning, and is supported by benefits and attributes. It is important to note that brand equity may contribute to long-term survival when it is not only rediscovered, but reinvented (Kapferer 2004).

Finally, some authors suggest that attributes, benefits and brand equity are closely interrelated. This relationship has been depicted as a pyramid or a laddering process. Davis (2000), for instance, proposes a pyramid with attributes at the base, benefits in the middle and values at the top (see Figure 1, below).

As Figure 1 shows, attributes help guide and strengthen brand benefits and values. The pyramid also shows that brand values are more difficult to deliver-yet more meaningful—than brand features and attributes. Other authors suggest that a laddering process starts with a set of attributes which lead to benefits which, in turn, support brand values (Kapferer 2004; Keller 2003). It is important to note that when the brand fails to move progressively up the ladder, it may suffer a reduction of alternative strategies for growth in the future (Keller 2003). 


\section{Journal of Evolutionary Studies in Business}

Figure 1. The Brand Value Pyramid

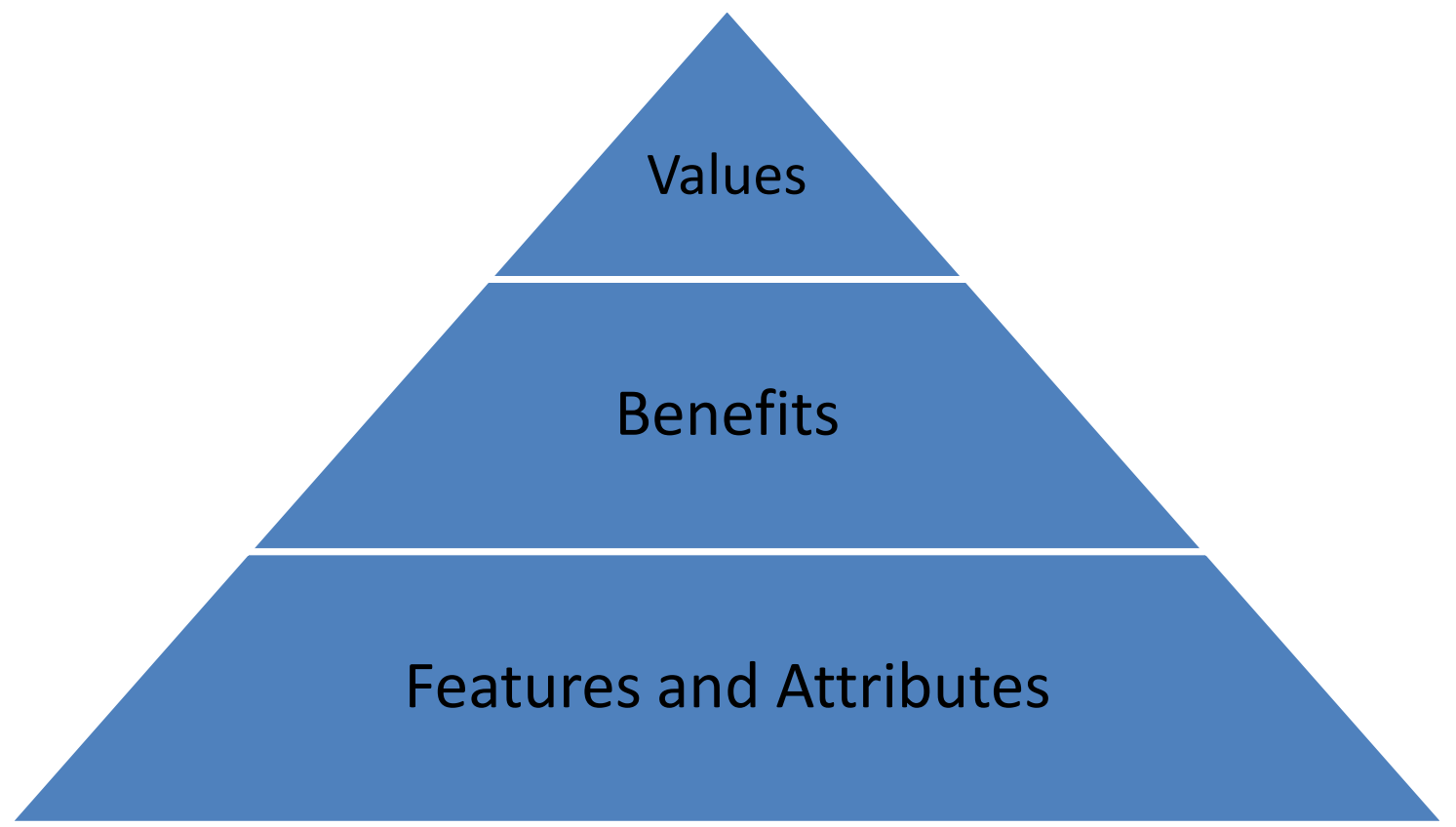

Source: Davis 2000

\section{Current brand-related issues}

There is no consensus classification for the brand concept. As in other research fields, most existing studies connect different brand concepts - and each journal and brand-specific conference adopts its own classification based on the papers that are presented. At the 9th Global Brand Conference in 2014 the papers were divided into the following sessions: "Luxury, love and loyalty to the brand", "Provocation and branding possibilities", "Brand location (country, city, ...) and brand heritage", "Corporate branding", "Co-creation", "Strategy and methodology", "Brand equity", and "Innovation". The same conference the following year divided sessions as follows: "Design and brand", "Relations with the brand", "Brand communities", "Brand names", "Brand identity", "Brand in emerging markets", etc. 
One of the leading journals in brand research, the Journal of Product and Brand Management, has recently published a review issue covering the last 25 years of publication. In that issue, the editors point out eight major shifts in the literature and three challenges for the future - shown below, in Table 2 .

Table 2. Shifts in brand research and future challenges

\begin{tabular}{|c|c|}
\hline Changes & $\begin{array}{l}\text { From brands as transactional tools managed from within companies to } \\
\text { brands as engagement entities co-created with others } \\
\text { - } \text { From interacting with brands as individuals to interacting with other } \\
\text { consumers and with brands collectively } \\
\text { - From consuming brands to experiencing brands } \\
\text { - } \quad \text { From measuring the strength of the brand to developing complex brand } \\
\text { equity systems } \\
\text { - From focusing on positive brand outcomes to managing negative brand } \\
\text { - } \text { outcomes } \\
\text { - From goods and services brands to brands of all different natures } \\
\text { introducing new methodological approaches } \\
\text { - From focusing on tangible brand characteristics to appreciating human- } \\
\text { like brand characteristics }\end{array}$ \\
\hline Challenges & $\begin{array}{l}\text { - Increased expected accountability and loss of control } \\
\text { - } \quad \text { Technology, brands, and speed of change } \\
\text { - } \quad \text { The increasingly global nature of markets }\end{array}$ \\
\hline
\end{tabular}

Source: Velotsou and Guzman (2017)

In light of this table, it can be seen that changes in brand research are primarily a result of changes in the environment. Most of these changes are also common to the rest of the marketing field, with aspects such as co-creation, engagement, or marketing experiences. These changes also point to the possibilities offered by new technologies to collect and analyze data on the Internet, or new methodologies based on neuro-marketing. With respect to the challenges, the increasingly difficult role of management due to the consumer empowerment - and consumer capacity to generate noise on the Internet and in the social networks-stand out. Other salient 
aspects include the increasingly global nature of markets, which leads brand managers to identify similarities among consumers in the development of brand associations.

In any case, there are many issues that brand research must face in the future. The development of models that integrate new trends and elements in research, the creation of tools for the analysis of consistency between all points of contact between the consumer and the brand, studies aimed at bringing together the perceptions, attitudes and behaviors of The different stakeholders, the creation of new metrics related to the brand and its connection with KPIs derived from the management of products and services, the development of new analytical tools to combine traditional brand metrics with new measures obtained from the big data, Or even the evolution of the brand concept itself and its dimensions over time will be aspects that will need to be addressed in the next few years (Hewett et al. 2016; Urde 2016; Velotsou and Guzman 2017).

\section{Brand \& family business}

Although the brand management literature is very extensive, this is not the case with the brand literature in family business contexts (Benavides et al. 2013). In addition to the reduced number of articles, none have been found in the major marketing magazines such as the Journal of Marketing, Journal of Marketing Research, or Journal of the Academy of Marketing Science. A recent review paper — specifically looking at the family firm context—is Beck (2016). This author provides an updated compilation of works in this field, which is why we will use this article as the main reference in these last two sections. Beck (2016) analyzes 41 brand management articles in the family business context, and brings out a series of future research questions. Next we will highlight some of the works reviewed by this author, but using a 
different classification system from the one used in his article. Although the organizational perspective may be useful for the analysis, there are jobs that are difficult to classify because they address aspects that would fit in several different categories (Brown et al. 2006). In order to simplify, a division of the study of brand into two groups can be established: (1) the brand identity elaboration and management by the organization and (2) the stakeholder brand perception. This second group would include the study of image, personality or brand reputation.

In the papers that analyze the brand identity built by the organization, the articles reviewed highlight certain differences and idiosyncrasies in the management of the family business compared to other companies, and the effects that this can have on the specific management of Corporate brand identity. Thus, there are studies that point out the greater continuity in management positions in family companies compared to other companies, which also provides greater stability in the type of policies followed in brand management. In some cases it is pointed out that family firms show greater vision in the long term (Bringham et al. 2014), while in other cases they show less market orientation than non-family firms (Zachary et al. 2011). Some studies highlight the flexibility in family business policies, their commitment and responsibility to the environment (Lyman 1991; Koiranen 2002), while other studies point to the existence of family conflicts that hinder management, and less willingness to employ CRM (Cooper et al. 2005; Matherne et al. 2011). In short, the review shows that the family business has a series of particularities that derive in both positive and negative aspects regarding the management of corporate brand vis-à-vis other companies.

With regard to the papers focusing on stakeholder brand perception, we can start by pointing out that the existence of a strong family brand that has endured several generations, with deeply- 
rooted history and values, and that achieved great achievements in the markets is a very valuable asset in the eyes of stakeholders (Blombäck and Brunninge 2013). This point is crucial to identity management, especially to the inside-out orientation. Hence, understanding the unique characteristics or essence of the brand - before moving on to develop other brand elementsis of particular relevance to family firms. This paper argues that family values may be unique, potentially contributing brand differentiation to brand identity. Given that values are the most meaningful and difficult to imitate, family businesses stand to enjoy strong differentiation when they establish family values as brand values. Furthermore, we argue that, while Davis (2000) suggests that values are the hardest to deliver in non-family firm contexts because it must be created and developed purposefully, brand value in family businesses may be organically continued by extension of family values - hence, greatly facilitating delivery.

Following the associative network theory, all this information regarding the values of the brand, essence and symbolism would lead to strengthening the brand node in the consumer's mind, giving it a positive, strong and unique meaning. That is why the family brand could be considered a source of competitive advantage in the market, with unique characteristics that would differentiate it from the rest. Similarly, and from signal theory, the existence of a positive brand associated with positive values would also reduce the uncertainty of consumers and other interest groups (Beck and Kenning 2015). This information would be a signal perceived by the consumer that the product or service has certain characteristics. This type of positive associations referred to a particular family business could also apply to family businesses in general. That is, if there are differences in the perception of family companies versus nonrelatives, this will lead to the existence of a series of associations that are common to all family businesses. Krappe et al. (2011) speaks of a brand of family business. 
As in the case of identity, studies have been carried out on the image and reputation of family corporate brands vis-à-vis non-family corporate brands, pointing out a series of positive and negative aspects of one versus the other. On the positive side, continuity in management translates into increased personal trust of the owner among clients, suppliers and employees (Dyer 2006; Sundaramurthy 2008), which also provides worker-related benefits such as increased job security and stability (Cabrera et al. 2011; Krappe et al. 2011). In terms of clients, it is noteworthy that customers may be more willing to establish a long-term relationship with family businesses than with non-family businesses. The image of these companies is, in general, trust, integrity and honesty (Carrigan and Buckley 2008). On the negative side, there are studies centered on students and unemployed people that show a worse perception of family businesses compared to other companies in aspects such as wages, contracting policies, resistance to change, or participation in company decision-making. In the case of consumers, they also perceive family firms as being less innovative, inefficient and stagnant (Krappe et al. 2011). In conclusion, we can point out that brand literature in family business contexts is scarce and focuses mainly on showing a series of positive and negative aspects of family businesses versus non-family businesses. In any case, a better or worse position of these companies with regard to others is not clearly observed. Based on the review of brand management, and the individuals highlighted in this section on brand research in the case of family businesses, the following section reflects on the potential areas of research of interest in this area of study.

\section{What to do}

Table 3 summarizes the six main lines of research proposed in this paper, three from the perspective of identity management, and three from the perspective of stakeholders. All are discussed in more detail in this paper. 
Table 3. Research proposals in family firm management

\begin{tabular}{|c|c|}
\hline $\begin{array}{l}\text { Identity } \\
\text { Management }\end{array}$ & $\begin{array}{l}\text { - Analysis of the interrelationships between family identity, corporate } \\
\text { identity management and commercialized products identity } \\
\text { management. } \\
\text { - Study of the determinants behind the visibility of family brand status } \\
\text { and its impact on brand management } \\
\text { - Analysis of the stability of the values that make up corporate identity } \\
\text { and link to family values }\end{array}$ \\
\hline $\begin{array}{l}\text { Stakeholder } \\
\text { Perceptions }\end{array}$ & $\begin{array}{l}\text { - Analysis of the interrelations between the perceptions of a given } \\
\text { family, the corporate brand of that family business and the brand of } \\
\text { the products sold by that company. } \\
\text { - Analysis of perceptions of the brand "family business" and their } \\
\text { impact on corporate brand personality and brand associations in } \\
\text { general. } \\
\text { - Analysis of the relationships between the different stakeholders } \\
\text { perceptions in family firms }\end{array}$ \\
\hline
\end{tabular}

Source: The authors, from Beck (2016)

The brand literature has revealed the interconnection between corporate identity and the identity of brands marketed by the company (Simoes et al. 2005). Thus, on the one hand, the identity of an organization determines the identity of each of the brands it sells. That is, top management establishes guidelines that delimit the identities of the brands in its portfolio. The objective being coherence between all of them, thus reinforcing the core values that will be common to all identities. On the other hand, the identity of all the brands that a company sells also determines the identity of the company as a whole. In this sense, all the actions developed by each of the trademarks help to define the identity of the company itself. This type of trademark identities — and, above all the brand image perceived by stakeholders — will condition corporate brand management.

Similarly, we can think that the particularities of the family business - family identity and their perceived image - will also influence identity and image management of the corporate brand 
and trademarks (see Figure 2). From the family business perspective, values are adhered to the same family values which the family members have been raised to praise.

Figure 2. Brand Interrelation

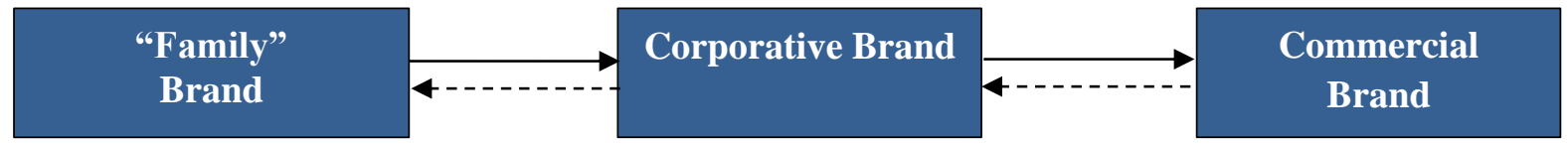

Source: own elaboration

Thus, the interrelationships between these three brands will focus future research, and their study can be approached from different angles. Following the same scheme outlined in the previous section, we will analyze the future lines of research around the two perspectives cited: on the one hand, the development and management of brand identity from the organization; And on the other hand, the brand perception by stakeholders.

From the perspective of the elaboration and management of the brand identity by the organization, we can start with the peculiarities in its management and see how they impact the way corporate identity is managed. Although there are several studies that analyze this impact (Shepherd and Haynie 2009; Parmentier 2011; Blombäck and Ramírez 2012), there is still much to study in this line of research. Beck (2016) speaks of the need to focus the study on the effects that moderate the relationship between the family brand identity and corporate brand identity. Because of heterogeneity in family businesses, it will be important to see to what extent the size, sector, or external constraints can affect the degree to which family identity and corporate identity are related. Finally, it is also interesting to analyze the relationship between corporate identity and the identity of the brands it markets. Although a priori is not so obvious, the specific characteristics of management in the family business can also affect the relationship between corporate identity and the identity of the product / service brands. This analysis will be 
especially relevant in the case of corporate brands with the same family name, or those that are easily linked to a family owner despite using a different name.

In line with this last comment, we can talk about a second major line of research focused on the visibility of the family brand in the company. Beck (2016) calls it the "family brand status". As in the previous case - and in spite of already existing studies (Kashmiri and Mahajan 2010; Zellweger et al. 2012) - there are aspects which require further investigate, such as the determinants of family predisposition to use its name in business. These types of factors will be closely linked to the risk that the owners wish to assume, since a greater recognition of family property can have reciprocal effects on the image of the company and the family. That is, a family conflict could have an impact on the company's image. Similarly, a company scandal could affect the image of the family (Memili et al. 2010; Botero et al. 2013). In studying such aspects, it could be interesting to start with a review of the brand extensions and alliances literature, in which the benefits and risks of this type of strategy are analyzed (Aaker and Keller 1990; Simonin and Ruth 1998; Keller, Aperia, and Georgson 2012). All this can end up influencing aspects such as the care with which aspects of the corporate brand are managed, or brand community management for the products that the company sells.

Another aspect of interest are the very components that comprise family business identity. Due to the greater continuity in management — and its effect on the stability of policies developed in the company-we may think that identity features will be more stable in these companies than other types of firms. There is an ongoing debate regarding the durability of identity values, with opinions closer to fostering enduring values that act as "anchors of meaning" (Csaba and Bengtsson 2006; Urde 2016) —in contrast to other opinions advocating adaptation (Balmer and Soenen 1999; Silveira et al. 2013). In this sense, it would be relevant to analyze the durability 
of these values that make up corporate identity in family businesses and their productsespecially those values that are common to the family identity.

From the point of view of the stakeholder brand perception, the future lines of research could be similar to those discussed above. Thus, perceptions of the brand are a reflection of the management of its identity, and therefore aspects such as the relationships between family identity and the identity of the company and its products, visibility of the family brand status, or stability in values Identities will affect the way in which consumers and other interest groups perceive the brand. The empirical work of Beck (2016) highlights the special importance that this type of perceptions have for family businesses and consulting. As a result, the image and reputation of family businesses can be further analyzed, and their effects on new variables of interest can be measured. Combining this line of research with marketing priorities and the future challenges of brand management (MSI 2017; Velotsou and Guzmán 2017), it could be encouraged to study how the positive and differential perceptions of family businesses translate into a greater commitment of its clients, and in a better economic results. For example, the greater confidence or greater commitment to the environment attributed to family businesses (Carrigan and Buckley 2008; Beck and Kenning 2015) could have an effect on customer lifetime value, Predisposition to speak well of the brand on the Internet (eWOM), or less sensitivity to negative brand-related information. This type of study would help to better understand the value of the family business compared to other companies, and would justify the importance of family business associations.

Following the associations scheme proposed by Keller (2003), associations linked to the family could bring meaning to the corporate brand and its products. The more visible and recognized by stakeholders the fact that the company is a family firm be, the greater the influence of family 
associations on the product. In this sense, it would be interesting to analyze, for example, the transmission between the personality of the family and the personality of the company and its products. A positive aspect of this visibility is that, for the stakeholders, it would be easier to personify the company because they would easily associate it with the owner or with a specific family.

As is true with the literature on consumer perceptions, it is possible to propose new research focused on brand perception on the part of other stakeholders. Studies of this sort would allow for a periodic analysis of stakeholder perceptions - or even of the relationships between perceptions, attitudes and behaviors of the different stakeholders with regard to the company. For example, if employees in a family business perceive greater stability and confidence on the part of management, it would be interesting to know the impact this may have on consumer perceptions, attitudes and behaviors. This type of research is in line with the current trend to tap different data sources such as employees and clients (Sirianni et al. 2013; Mullins et al. 2014, and Palmatier 2016).

In short, we can conclude by saying that the literature on brand and family business has interesting issues to address in the future. Approaching these two lines of research is crucial for family firms if they are to exploit their potential to create a strong brand and survive in the market.

\section{References}

Aaker, David A. 1996. Building Strong Brands. New York: The Free Press

Aaker, David A. 1997. "Dimensions of brand personality." Journal of Marketing Research 34 (3): 347356.

Aaker, David A., and Kevin L. Keller. 1990. "Consumer Evaluations of Brand Extensions.” Journal of Marketing 54 (1): 27-41. 
Aaker, David A., and Erich Joachimsthaler. 2000. "The brand relationship spectrum: The key to the brand architecture challenge." California Management Review 42 (4): 8-23.

Ahluwalia, Rohini, and Zeynep Gürhan-Canli. 2000. "The effects of extensions on the family brand name: An accessibility-diagnosticity perspective." Journal of Consumer Research 27 (3): 371381.

AMA - American Marketing Association. 2017. Dictionary. Accessed February 23, 2017. https://www.ama.org/resources/pages/dictionary.aspx?dLetter=B

Arnold, David.1992. The Handbook of Brand Management. London: Century Business.

Balmer, John M.T., and Guillaume B. Soenen. 1999. "The ACID test of corporate identity management." Journal of Marketing Management 15:69-92.

Batra, Rajeev, Aaron Ahuvia, and Richard P. Bagozzi. 2012. "Brand love." Journal of Marketing 76 (2): $1-16$.

Beck, Susanne. 2016. "Brand management research in family firms. A structured review and suggestions for further research." Journal of Family Business Management 6 (3): 225-250.

Beck, Susanne, and Peter Kenning. 2015. "The influence of retailers' family firm image on new product acceptance: an empirical investigation in the German FMCG market." International Journal of Retail and Distribution Management 43 (12): 1126-1143.

Benavides, Carlos A., Cristina Quintana, and Vanesa F. Guzmán. 2013. "Trends in family business research.” Small Business Economics 40 (1): 41-57.

Bhattacharya, Chitrabhan B., and Sankar Sen. 2003. "Consumer - company identification: a framework for understanding consumers' relationships with companies." Journal of Marketing 67 (2): 7688.

Blombäck, Anna, and Marcela Ramírez. 2012. "Exploring the logics of corporate brand identity formation." Corporate Communications: An International Journal 17 (1): 7-28.

Blombäck, Anna, and Olof Brunninge. 2013. "The dual opening to brand heritage in family businesses." Corporate Communications: An International Journal 18 (3): 327-346.

Botero, Isabel C., Jill Thomas, Christopher Graves, and Tomasz A. Fediuk. 2013. "Understanding multiple family firm identities: an exploration of the communicated identity in official websites." Journal of Family Business Strategy 4 (1): 12-21.

Brigham, Keith H., G. Tom Lumpkin, G. Tyge Payne, and Miles A. Zachary. 2014. "Researching longterm orientation a validation study and recommendations for future research." Family Business Review 27 (1): 72-88. 
Brown, Tom J., Peter A. Dacin, Michael G. Pratt, and David A. Whetten. 2006. "Identity, intended image, construed image, and reputation: an interdisciplinary framework and suggested terminology." Journal of the Academy of Marketing Science 34 (2): 99-106.

Cabrera, M.Katisuka, M. de la Cruz Deniz, and Josefa D. Martin. 2011. "Familiness and market orientation: A stakeholder approach.” Journal of Family Business Strategy 2:34-42.

Carrigan, Marylyn, and Joan Buckley. 2008. “What's so special about family business?' An exploratory study of UK and Irish consumer experiences of family businesses." International Journal of Consumer Studies 32 (6): 656-666.

Christensen, Thoger, and Seren Askegaard 2001. "Corporate identity and corporate image revisited." Journal of Advertising Research 35 (3/4): 292-315.

Cooper, Marjorie J., Nancy Upton, and Samuel Seaman. 2005. "Customer relationship management: a comparative analysis of family and nonfamily business practices." Journal of Small Business Management 43 (3): 242-256.

Csaba, Fabian F., and Anders Bengtsson. 2006. "Rethinking identity in brand management." In Brand culture, edited by Schroeder J.E. and Salzer-Mörling, M., 118-135. Oxon, UK: Routledge.

Czellar, Sandor. 2003. "Consumer attitude toward brand extensions: an integrative model and research propositions." International Journal of Research in Marketing 20:97-115.

Davis, Scott. 2000. Brand Asset Management. San Francisco: Jossey-Bass.

De Chernatony, Leslie, Fiona Harris, and Francesca Dall'Olmo Riley. 2000. "Added value: Its nature, roles and sustainability." European Journal of Marketing 24 (1/2): 39-56.

De Chernatony, Leslie, and Michael McDonald. 2003. Creating Powerful Brands in Consumer, Service and Industrial Markets, 3rd Edition. Oxford: Elsevier.

De Chernatony, Leslie. 2006. From Brand Vision to Brand Evaluation. Oxford: Elsevier ButterworthHeinemann.

Dyer, W. Gibb. 2006. "Examining the 'family effect' on firm performance." Family Business Review 19 (4): 253-273.

Fournier, Susan. 1998. "Consumers and Their Brands: Developing Relationship Theory in Consumer Research.” Journal of Consumer Research 24 (4): 343-373.

Ghodeswar, Bhimrao M. 2008. "Building brand identity in competitive markets: A conceptual model." Journal of Product and Brand Management 17 (1): 4-12.

Griffin, Abbie, and John R. Hauser. 1993. "The voice of the customer." Marketing Science 12 (1): 1-27. Hertfordshine Business School. 2014. "9th Global Branding Conference.” Hatfield, UK, April 9-11.

Hewett, Kelly, William Rand, Roland T. Rust, and Harald J. van Heerde. 2016. "Brand buzz in the echoverse." Journal of Marketing 80 (3): 1-24. 
Ind, Nicholas. 1990. The Corporate Image. London: Kogan Page.

Ind, Nicholas, and Rune Bjerke. 2007. Branding Governance. Chichester: John Wiley \& Sons.

Joachimsthaler, Erich, and David Aaker. 1997. "Building brands without mass media." Harvard Business Review, January-February.

Kapferer, Jean N. 2004. The New Strategic Brand Management: Creating and Sustaining Brand Equity Long Term. London: Kogan Page.

Kashmiri, Saim, and Vijai Mahajan. 2010. "What's in a name?: an analysis of the strategic behavior of family firms." International Journal of Research in Marketing 27 (3): 271-280.

Keller, Kevin L. 1993. "Conceptualizing, measuring, and managing customer-based brand equity." Journal of Marketing 57 (1): 1-22.

Keller, Kevin L. 2000. "The brand report card." Harvard Business Review 78 (1): 147-56.

Keller, Kevin L. 2003. "Brand Synthesis: The multidimensionality of brand knowledge." Journal of Consumer Research 29:595-600.

Keller, Kevin, Tony Apéria, and Mats Georgson. 2012. Strategic Brand Management. A European Perspective. U. K.: FT Prentice Hall, Pearson Education.

King, Stephen. 1991. "Brand-building in the 1990s." Journal of Consumer Marketing 8 (4): 43-52

Koiranen, Matti. 2002. "Over 100 years of age but still entrepreneurially active in business: exploring the values and family characteristics of old Finnish family firms." Family Business Review 15 (3): 175-187.

Kotler, Philip. 1991. Marketing Management (Seventh ed.). Englewood Cliffs, NJ: Prentice-Hall.

Kotler, Philip, G. Armstrong, J. Saunders, and V. Wong. 2002. Principles of Marketing. London: FT Prentice Hall.

Krappe, Alexander, Lazaros Goutas, and Arist von Schlippe. 2011. "The 'family business brand': an enquiry into the construction of the image of family businesses." Journal of Family Business Management 1 (1): 37-46.

Levitt, Theodore. 1980. "Marketing success through differentiation-of anything." Harvard Business Review, January 1980. Accesed February, 2017. https://hbr.org/1980/01/marketing-successthrough-differentiation-of-anything

Lyman, Amy R. 1991. “Customer service: does family ownership make a difference?” Family Business Review 4 (3): 303-324.

Matherne, Curtis F., J. Ring, and D'Lisa Mckee. 2011. "Multiple social identifications and the family firm." Journal of Behavioral and Applied Management. 13(1): 24.

Melewar, T. C., and John Saunders. 1998. "Global corporate visual identity systems." International Marketing Review 15 (4): 291-313. 
Memili, Esra, Kimberly A. Eddleston, Franz W. Kellermanns, Thomas M. Zellweger, and Tim Barnett. 2010. "The critical path to family firm success through entrepreneurial risk taking and image." Journal of Family Business Strategy 1 (4): 200-209.

Mullins, Ryan R., Michael Ahearne, Son Lam, Zachary R. Hall, and Jeffrey Boichuk. 2014. "Know your customer: How salesperson perceptions of customer relationship quality form and Influence Account Profitability." Journal of Marketing 78:38-58.

MSI - Marketing Science Institute. 2016. Research Priorities 2016-2018. Accessed February 23, 2017. http://www.msi.org/uploads/articles/MSI RP16-18.pdf

Nandan, Shiva. 2005. "An exploration of the brand identity-brand image linkage: A communications perspective." Journal of Brand Management 12 (4): 264-78.

Pappu, Ravi, and Pascale G. Quester. 2016. "How does brand innovativeness affect brand loyalty?" European Journal of Marketing 50 (1/2): 2-28.

Palmatier, Robert W. 2016. "Improving publishing success at JAMS: contribution and positioning." Journal of the Academy of Marketing Science 44 (6): 655-659.

Pansari, Anita, and V. Kumar. 2016. "Customer engagement: the construct, antecedents and consequences." Journal of the Academy of Marketing Science 45 (2): 164-185.

Parmentier, Marie-Agnès. 2011. "When David met Victoria forging a strong family brand." Family Business Review 24 (3): 217-232.

Porter, Michael E. 1980. Competitive Advantage: Techniques for Analyzing Industries and Competitors. London: Free Press.

Rao, Akshay R., Lu Qu, and Robert W. Ruekert. 1999. "Signaling unobservable product quality through a brand ally." Journal of Marketing Research 36 (2): 258-268.

Reuber, Rebecca, and Eileen Fischer. 2011. "Marketing in the family firms." Family Business Review 24 (3): 193-196.

Riezebos, Rik. 2003. Brand Management: A Theoretical and Practical Approach. London: FT Prentice Hall.

Shepherd, Dean, and J. Michael Haynie. 2009. "Family business, identity conflict, and an expedited entrepreneurial process: a process of resolving identity conflict." Entrepreneurship Theory and Practice 33 (6): 1245-1264.

Sheth, Jagdish B., Bruce I. Newman, and Barbara L. Gross. 1991. "Why we buy what we buy: A theory of consumption values." Journal of Business Research 22 (2): 159-70.

Silveira, Catherine, Carmen Lages, and Cláudia Simões. 2013. "Reconceptualizing brand identity in a dynamic environment." Journal of Business Research 66:28-36. 
Simoes, Cláudia, Sally Dibb, and Raymond P. Fisk. 2005. "Managing corporate identity: An internal perspective." Journal of the Academy of Marketing Science 33 (2): 153-168.

Simonin, Bernand L., and Julie A. Ruth. 1998. "Is a company known by the company it keeps? Assessing the spillover effects of brand alliances on consumer brand attitudes." Journal of Marketing Research 35 (1): 30-42.

Sirianni, Nancy J., M.J. Bitner, S.W. Brown, and N. Mandel. 2013. "Branded Service Encounters: Strategically Aligning Employee Behavior with the Brand Positioning." Journal of Marketing $77: 108-123$.

Spanish Trademark Law 17/2001. BOE-Boletin Oficial del Estado 294, December 8, 2001. Accessed February, 2017. Ref. BOE-A- 2001-23093. https://www.boe.es/buscar/doc.php?id=BOE-A2001-23093

Stach, Jennifer. 2015. "A conceptual framework for the assessment of brand congruent sensory modalities." Journal of Brand Management 22 (8): 673-694.

Sundaramurthy, Chamu. 2008. "Sustaining trust within family businesses." Family Business Review 21 (1): 89102.

Urde, Mats. 2016. "The brand core and its management over time." Journal of Product and Brand Management 25 (1): 26-42.

Velotsou, Cleopatra, and Francisco Guzman. 2017. "The evolution of brand management thinking over the last 25 years as recorded in the Journal of Product and Brand Management." Journal of Product and Brand Management 26 (1): 2-12.

Vernuccio, Maria, Margherita Pagani, Camila Barbarossa, and Alberto Pastore. 2015. "Antecedents of brand love in online network-based communities. A social identity perspective." Journal of Product and Brand Management 24 (7): 706-719.

Yakimova, Raisa, and Michael Beverland. 2005. "The brand-supportive firm: An exploration of organisational drivers of brand updating." Journal of Brand Management 12 (6): 445-60.

Zachary, Miles A., Aaron Mckenny, Jeremy Collin Short, and G.Tyge Payne. 2011. "Family business and market orientation construct validation and comparative analysis." Family Business Review 24 (3): $233-251$.

Zellweger, Thomas M., Franz W. Kellermanns, Kimberly A. Eddleston, and Esra Memili. 2012. "Building a family firm image: how family firms capitalize on their family ties." Journal of Family Business Strategy 3 (4): 239-250.

This is an Open Access article distributed under the terms of the Creative Commons Attribution-Non-Commercial-No Derivatives License (http://creativecommons.org/licenses/by-nc-nd/4.0/), which permits non-comercial re-use and distribution, provided the original work is properly cited, and is not altered or transformed in any way. 